\title{
A plea for quality in internship programmes - evidence from the business and administration students' experience
}

\author{
Simona GOIA (AGOSTON) \\ The Bucharest University of Economic Studies, Bucharest, Romania \\ simona.goia@ase.ro \\ Cristian Virgil MARINAȘ \\ The Bucharest University of Economic Studies, Bucharest, Romania \\ Ramona Ștefania IGRET \\ The Bucharest University of Economic Studies, Bucharest, Romania
}

\begin{abstract}
The career of business students is nowadays definitely influenced by their involvement in different internships and volunteering activities. The internship programmes help them understand the context of business organisations and decide what field of activity is most suitable for their professional life. However, sometimes internship programmes are not very well organised and influence in a negative manner students' final perception of a certain domain. Our research identified and analysed the main factors that might influence the quality of an internship programme from students' perspective. The quantitative analysis relies on a questionnaire based survey among over 450 students from one of the most prestigious universities in Romania in the field of economics and business administration. By running factor analysis, we identified five factors which mainly determine the quality of internships: Job arrangements, Mentorship and employability benefits, Learning content, Academic supervision, Bureaucracy and accessibility. Subsequently we measured through multiple regression the way the identified factors influence the quality of the internships. We consider that the results of the study are relevant not only for academics but also for students and business organisations that have the power and instruments to improve internship programmes and the entire experience for all stakeholders involved.
\end{abstract}

Keywords: internship programmes, quality of internship, business and administration students, students' expectations, quality factors, multiple regression.

Please cite the article as follows: Goia (Agoston), S., Marinaș, C.M. and Igret, R.Ș. (2017), “A plea for quality in internship programmes - evidence from the business and administration students' experience", Management \& Marketing. Challenges for the Knowledge Society, Vol. 12, No. 1, pp. 49-60. DOI: 10.1515/mmcks-2017-0004.

\section{Introduction}

Internship programmes are becoming important steps in the future career of students from various fields of study. They are highly relevant also for business and administration students, as they are often exposed to a wide range of information from different subareas of their field of study (e.g. from marketing to finance and human resources) and without hands-on experience it is difficult for them to select a suitable area to focus on in their professional development. On the one hand, the volunteering or sometimes even paid internships help them decide in which field of activity they want to develop a professional career. The internships allow students to 
identify those organisations that share the same organisational culture as their own values. Last but not the least, these programmes make them understand the importance of person - job fit and person - organisation fit (Dessler, 2013). On the other hand, the organisations are claiming gaps between the theoretical background of business students and their practical knowledge (Baskar, 2009). Therefore, in order to meet their requirements students must understand the business environment and be prepared for certain practical issues, in order to become 'ready-to-use professionals'. It is desired that the throughputs of the universities are in line with the customer requirements (Prabhu and Kudva, 2016). That is why the use of internship programmes and cooperative education schemes increased substantially over the past decades (Beck and Halim, 2008).

In Romania, there are different schemes of fostering the institutionalisation and professionalization of internship programmes. One major resource is represented by European funding, accessed also by higher education institutions. Our research is part of a wider study regarding the quality of internships in the Romanian context. The study was conducted on undergraduate and master students of the Bucharest University of Economic Studies, during the academic year 2014-2015, within the project "Human Resources Internships for Students - PREUS", contract POSDRU/161/2.1/G/137915, co-funded from European Social Fund under 20072013 Sectoral Operational Program for Human Resources Development.

During this research, the main factors influencing the quality of an internship were identified using a clustering method for variables called factor analysis. Based on the variables resulted from the factor analysis it was developed a regression model whose main objective was to ascertain whether the above-mentioned variables exert a positive or a negative influence on the perceived quality of internship programmes and if any, to quantify it. By acknowledging the factors which determine the quality of internship programmes, the stakeholders involved can formulate also policies and measures and develop efficient tools in order to improve the quality of internship programmes in Romania.

Therefore, the present article seeks to answer some important questions: which are the main factors which influence the quality of internship programmes from the perspective of business and administration students'? Which factors exert the greatest influence and how can be this outcome translated into practical knowledge?

The article is structured into three main parts: in the first section, literature review, there are outlined the main goals and advantages of internship programmes from the perspective of different stakeholders involved in the process. Based on several other researches conducted in various fields of economics and business administration there are identified various factors which determine the quality of internship programmes. The next section of the paper is dedicated to the research methodology and explanation of the methods deployed. Next, the results obtained are critically discussed and there are formulated recommendations in order to improve the quality of internship programmes. There are mentioned also the limits of the study and potential research developments in the future. 


\section{Literature review}

\section{Stakeholders' advantages of internship programmes}

The European Quality Charter on Internships and Apprentiships defines internships as work-based learning opportunities during which a person spends some time in an organisation in order to acquire competencies requested by the labour market.

The main objective of internship programmes is to facilitate students' transition from school to professional life. The programmes must have clear goals and be well planned in order to meet the expectations of youngster and to give them the opportunity to experience the working life in a certain environment (Hurst and Good, 2010). Unfortunately, today many internships are offering little education value and instead they replace real entry-level jobs, with none of the security and value of the real job (European Youth Forum, 2016).

The benefits of internships are related to a large number of stakeholders. However, specialists emphasise that the main impediments to the success of these programmes are related to the gaps between stakeholders and their insights about internships (Prabhu and Kudva, 2016).

For students, internship learning represents an essential tool for completing their formal education, conditioning their further career path (Shu-Tai and ChengChung, 2015). Moreover, Canon and Arnold (1998) stated that students consider internships a means of gaining competitive advantage on the labour market and a tool to find a first job experience because students who undertook internships tend to receive more job offers (Beck and Halim, 2008). One major benefit for students is also the injection of reality into abstract lectured theory (O'Hara and Shaffer, 1995), internships providing platforms to touch authentic context (Tang, 2012).

Generally speaking, universities declare themselves open to facilitate internships experiences. However, they rarely provide the institutional support, unless there is potential monetary gain (Bay, 2006). In many situations, the internships also provide a tutor from inside the university. Unfortunately, these tutors have sometimes only an advisor role, office based. As emotions influence learning, the role of a teacher as tutor should be very important (Radu, 2014) in leading the practical activity of interns. However, most faculties don't have enough resources and knowledge to advice on career prospects (Bay, 2006). Indeed, nowadays many Romanian universities have career advising specialists (Staiculescu et al., 2015). Their role should be strongly related to further internship programmes, as they can have relevant influence when students must choose from multiple internships. The career counselling specialists have the necessary experience to link the professional profile of the students to a certain organisation and internship/first job. However, very often career centres play a rather formal role, career counsellors are overloaded and the ratio students/counselling specialist is very high, so that do not have enough time and resources to provide proper counselling services and conduct in-depth discussions with each student.

The organisations that host internships have multiple benefits. First of all, they sometimes benefit of unpaid work or very low paid work done by enthusiast young people. During these stages, the organisations can evaluate the potential of the interns 
without making a firm commitment regarding future employment (Beck and Halim, 2008). Secondly, the internship can be understood as a long - term selection process after which the employer will select the best candidates. Last but not least, the organisations are promoting their image and employer brands through internship programmes. They organise in universities events and presentations related to internship programmes where they promote the brand, the products and services, the managerial team and the entire image of the company. They relate marketing campaigns to internships in order to gain competitive advantage on the labour market. Studies regarding the motivation of organisations in conducting internships also emphasise the sometimes-philanthropic reason of organising and encouraging internships (Bailey, Hughes and Barr, 2000).

\section{Quality internships}

The quality of internships is a much-debated subject in the education research. A significant number of studies identified different predictors of the quality of internships like adequate design and good organisation (Coll et al. 2009), structural and curricular issues, grading systems and quality of the internships coordinator (Gryski, Johnson and O'Tool, 1987), programmes objectives, the interns preparation, evaluation of interns and the internship programmes (Alpert, Heaney and Luhn, 2009), quality of workplace supervision or host organisation practices and policies (Beard and Morton, 1999). For example, in sport areas, the quality of internships depends on physical, technical and human resources available, in particular the skills of the academic coordinator, the internship coordinator (Chouinard, 1993) whose tasks of organizing integrative seminars before, during and after internship significantly support the students to make full benefit of the internships. The table below is summarising the main research focus of some studies on quality in regards to internships from various fields of study.

Table 1. Research on quality of internships

\begin{tabular}{|l|l|}
\hline Authors & Main research focus \\
\hline Knouse et al., 1999 & $\begin{array}{l}\text { The study demonstrates the positive relationship between } \\
\text { business college internships and the college performance and } \\
\text { future job opportunities. }\end{array}$ \\
\hline Gaudreau et al., 2006 & $\begin{array}{l}\text { The article is analysing SREB recommendations for states seeking } \\
\text { to improve quality internships: (a) ensure that state guidelines for } \\
\text { internships are based on research for effective school leadership, } \\
\text { (b) develop a valid and reliable performance evaluation system, } \\
\text { and c) provide comprehensive training to all mentor principals. }\end{array}$ \\
\hline Hurst and Good, 2010 & $\begin{array}{l}\text { The research is an analysis of five dimensions as trends/changes } \\
\text { in internships programmes and the benefits for students, retailers } \\
\text { and universities. }\end{array}$ \\
\hline Shoenfelt et al., 2012 & $\begin{array}{l}\text { The article focuses on identifying means of delivering productive } \\
\text { and useful internships experiences for industrial/organisational } \\
\text { psychology students by developing appropriate internship sites } \\
\text { and finding strategies for monitoring and evaluating the interns. }\end{array}$ \\
\hline Ching-Sung and Chen-Wei, 2013 & $\begin{array}{l}\text { The study identifies internship organisation factors affecting } \\
\text { students 'employment intentions: interpersonal recognition, }\end{array}$ \\
\hline
\end{tabular}

Vol. 12, No. 1, Spring, pp. 49-60, ISSN 1842-0206 | Management \& Marketing. Challenges for the Knowledge Society 


\begin{tabular}{|l|l|}
\hline & $\begin{array}{l}\text { benefit, supervisor } \\
\text { leadership, job arrangement, and training. }\end{array}$ \\
\hline Cuyler and Hodges, 2015 & $\begin{array}{l}\text { The research is analysing the expectations of arts and cultural } \\
\text { management students in respect to quality internships and the } \\
\text { differences generated by the country of origin, gender, enrolment } \\
\text { status. }\end{array}$ \\
\hline
\end{tabular}

Source: Authors' own synthesis.

The study conducted by Knemeyer and Murphy in 2002 surveyed internships undertaken by logistics students and non-logistics students (students studying various other business fields). Students surveyed strongly considered that internships should be designed in such a way so to develop their job-related skills (mean score 4.37 out of 5), to enhance their full time hiring opportunities (mean score 4.45 out of 5 ) and to provide to them training in latest technology (mean score 4.37 out of 5); these perceptions were more present in case of non-logistic students (mean scores relatively higher) as compared to logistics students. Based on the conclusions of this study we could assume that, in logistics and related fields, students' interest in undertaking internships is significantly influenced by the learning outcomes and their contribution to career start and development.

Another study completed in 2006 (Starr-Glass, 2006) on business students of an American College in Prague undertaking internships in Czech Republic, Croatia, Hungary, Slovakia and Austria assessed students' perceptions about business internships against several variables, namely: situation specific learning, competence training, product and instrumentality, terminal engagements, acceptance practice encountered. The Starr-Glass's study revealed that: (a) all interns surveyed reported positive learning experience related to specific tasks, but limited to the activities of the departments they were interns to; (b) interns generally reported they had learnt new skills and there had been a broadly consensus among interns related to the difference between the theory they had learnt in formal business education and how corporation managers actually had done business; (c) the educational component of the internships focused on specific company's products or activities, but not on business processes and interns still considered the internships as a "plus" for their future employment.

Another survey conducted in hospitality industry (Girard, 1999) investigated students' perceptions about internships within various organisations from USA. The survey consisted in distributing 120 questionnaires to interns in hospitality industry (with the support of internships coordinators) and enjoyed a 57.5\% rate of useable responses. The research focused on three variables: work content, supervision and appraisals. Main findings of the survey indicated that: (a) the content of the work has been considered as a motivator, at the core of the satisfaction of interns having the potential to trigger interns' responsibility $(98.2 \%$ of the interns felt responsible for their work); relevant items for the interns covered workload, their engagement into day to day problems and activities at work, received recognition and acknowledgement for their work; (b) the supervisor plays an important role (organising and appraising interns job performance and mentor) providing also leadership patterns for interns: it is the supervisor who encourages interns to ask 
questions (according to 84.3\% of the students surveyed), to assist the interns in solving problems (according to $84.3 \%$ of the surveyed interns) and to supervise and guide interns work (80.7\% of the respondents); (c) performance appraisal remains important for promotions and career advancement; interns appraisals are mandatory and should be directed towards their progress and explained to them.

\section{Methodology}

In order to assess the quality of internship programmes it was conducted a questionnaire based survey among students from Bucharest University of Economic Studies in 2015. The target group is represented by undergraduate and graduate students from different study programmes in the fields of economic and business administration (Business Administration in Foreign Languages, Agribusiness, Finance and Banking, Public Administration, Human Resources etc.) within one of the most prestigious universities in Romania, namely Bucharest University of Economic Studies. Over 450 valid answers were collected and used within the present analysis.

The questionnaire was distributed in physical and electronic form (on a platform specially created for this purpose) and comprises four main parts: the first one refers to demographics of the respondents (age, gender, field of study etc.), the second one to the direct observable features of the internships such as type of organisation where it was conducted, how it was identified and selected, period of time when it was conducted etc. The third part of the questionnaire comprises 30 items which aim at assessing on one hand, the perceived quality of internship programmes among respondents and on the other hand, the factors which determine and lead to a certain level of quality. The fourth part of the questionnaire comprises open questions, where students can express their opinion about positive and negative aspects experienced during the internship and also provide suggestions for the improvement of these programmes.

For the current paper the most relevant part of the questionnaire is the third one. The 30 items are formulated on a 5-Point-Likert scale which assesses the degree respondents agree or disagree with the statement as follows: 5- strongly agree, 4agree, 3- neither agree nor disagree, 2- disagree, 1- strongly disagree. The initial items of the questionnaire were formulated after analyzing several similar studies from other countries/fields. The authors organized two focus groups which brought together various stakeholders: students, members of the academic community, representatives of organizations. Considering the input and comments obtained from the focus group the initial form of the questionnaire was amended and updated. The resulting questionnaire was used in the present study.

The subsequent quantitative analysis is based on two major methods: factor analysis and regression. Factor analysis is a dimension reduction method by clustering a larger number of items (from a questionnaire) which converge to common ideas or concepts, which are instrumentalized in form of latent underlying variables. In social sciences researchers deal very often with abstract phenomena and concepts which are difficult to measure. Questionnaires try to do that, but the output, if not properly structured and depicted, might be fuzzy and overwhelming. Factor 
analysis aims at grouping large number of items based on covariance and correlation in subsets, which are called factors. The items within a factor should be strongly correlated between each other, while the resulting factors are relatively independent of one another (Craciun et al., 2015). In our case, after running the factor analysis, resulted five factors-determinants of quality internship programmes, which represented also the independent variables which were used in the regression model depicted in the present paper. The statistical technique used in the present factor analysis was varimax orthogonal rotation, which aims at maximizing the dispersion of factor loading within each factor. Various tests such as: Kaiser-Meyer-Olkin (KMO)aimed at assessing the adequacy of the sample-, Bartlett's Test of sphericity - which indicates that matrix R differs from the unit matrix-, Cronbach's Alpha coefficientwhich assesses the internal consistency of the scale- revealed very good results, meaning that the five factors resulted from the analysis are relevant for our further analysis and also reliable regarding the phenomenon studied.

Based on the factor analysis the following linear multiple regression model was elaborated. The dependent variable represents the quality of the internship programme (as assessed by respondents) and is based upon five items from the questionnaire. The five predictor (independent) variables are the five factors resulted from the factor analysis conducted before. In our case the five factors are:

Factor 1 (X1) - Job arrangements: contains questions related to induction period in the organization, working schedule, feedback received, clear cut responsibilities which are properly communicated to the intern, relevance and usefulness of the work performed;

Factor 2 (X2)- Mentorship and employability benefits: contains questions related to the relations with the internship coordinator and the support offered to the intern by him/her, availability of other colleagues to mentor the intern, relevance of acquired knowledge for the future career;

Factor 3 (X3) - Learning content: contains questions related to the relation between the activities performed in the organisation and the knowledge acquired at university, the relation between field of studies and field of activity, the capacity to apply theoretical information at the internship place;

Factor 4 (X4) -Academic supervision: contains questions related to the relation with the academic supervisor and other members of the faculty, the evaluation procedures within the faculty, information related to the internship provided at the faculty;

Factor 5 (X5) - Bureaucracy and accessibility: contains questions related to the bureaucratic procedures related to the internship and the accessibility to the internship place.

$\mathrm{Y}=\mathrm{b}_{0}+\mathrm{b}_{1} \mathrm{X}_{1}+\mathrm{b}_{2} \mathrm{X}_{2}+\ldots \ldots \ldots \ldots \ldots \ldots+\mathrm{b}_{\mathrm{n}} \mathrm{X}_{\mathrm{n}}$

where

$\mathrm{Y}=$ dependent variable

$\mathrm{b}_{0} \ldots \mathrm{b}_{\mathrm{n}}=$ unknown parameters

$\mathrm{X}_{1} \ldots \mathrm{X}_{\mathrm{n}}=$ independent variables

There is also an error term $\varepsilon$. 


\section{Results and discussion}

The regression model and the estimated parameters (ordinary least squares) are presented in the following tables:

Table 2. Regression model

\begin{tabular}{|l|l|l|l|l|l|}
\hline Model & R & R square & Adjusted R square & Std. Error of the Estimate & Durbin-Watson \\
\hline 1 & $.730^{\mathrm{a}}$ & .532 & .527 & 3.45049 & 2.135 \\
\hline
\end{tabular}

Notes: Predictors: (Constant), Job arrangements, Mentorship and employability benefits, Learning content, Academic supervision, Bureaucracy and accessibility.

b. Dependent variable: Quality of internship programmes.

Table 3. ANOVA

Source: Authors' own research.

\begin{tabular}{|l|r|r|r|r|r|}
\hline Model & \multicolumn{1}{l|l}{$\begin{array}{l}\text { Sum of } \\
\text { squares }\end{array}$} & df & Mean square & F & Sig. \\
\hline 1 Regression & 6124.260 & 5 & 1224.852 & 102.878 & $.000^{\mathrm{a}}$ \\
Residual & 5381.452 & 452 & 11.906 & & \\
Total & 11505.712 & 457 & & & \\
\hline
\end{tabular}

Table 4. Coefficients

\begin{tabular}{|l|r|r|r|r|r|}
\hline \multirow{2}{*}{ Model } & \multicolumn{2}{|c|}{$\begin{array}{c}\text { Unstandardized } \\
\text { coefficients }\end{array}$} & \multicolumn{2}{c|}{$\begin{array}{c}\text { Standardized } \\
\text { coefficients }\end{array}$} & \multirow{2}{*}{ Sig. } \\
\cline { 2 - 5 } & \multicolumn{1}{c|}{$\mathrm{B}$} & \multicolumn{1}{c|}{ Std. Error } & \multicolumn{2}{c|}{ Beta } & \\
\hline 1. (Constant) & 17.459 & .161 & & 108.283 & .000 \\
\hline Job arrangements & 1.658 & .161 & .330 & 10.270 & .000 \\
\hline $\begin{array}{l}\text { Mentorship and } \\
\text { employability benefits }\end{array}$ & 1.940 & .161 & .387 & 12.021 & .000 \\
\hline Learning content & 2.237 & .161 & .446 & 13.857 & .000 \\
\hline Academic supervision & 1.188 & .161 & .237 & 7.358 & .000 \\
\hline $\begin{array}{l}\text { Bureaucracy and } \\
\text { accessibility }\end{array}$ & .690 & .161 & .137 & 4.272 & .000 \\
\hline
\end{tabular}

Dependent variable: Quality of internship programme

Source: Authors' own research.

The summary of the regression model reveals that the value of $\mathrm{R}$ square is 0.532 , which means that the five independent variables from the model can provide explanations for $53 \%$ of the changes occurred in the value of the dependent variable. Therefore, Job arrangements, Mentorship and employability benefits, Learning content, Academic supervision, Bureaucracy and accessibility are responsible to a large extent (over 50\%) for the quality of internship programmes.

Adjusted R square provides information about the capacity of generalizing the model among the population of the sample and in the ideal case it is expected that its values are very close to the values of $\mathrm{R}$ square. In our case the difference is small, namely 0.5. Durbin-Watson statistics offers information about errors' correlation and a value very close to 2 (in the present case 2.135 ) indicates that errors are not autocorrelated.

By analyzing the table ANOVA (F= 102.87 și Sig= .000) it can be observed that the model has a good prediction capacity. 
In Table 3 are illustrated the regression coefficients. It might be observed that in the case of all coefficients Sig. is 0, which implies that all of them are statistically significant. The constant has the value 17.45 meaning that the regression curve intersects the vertical axe in this point. The value of all five coefficients are positive, meaning that each of the selected factors exerts a positive influence on the quality of internship programmes. Assessing the individual contribution of each factor to the quality of internship programmes, it can be observed that the greatest influence is exerted by the factor "Learning content": if the value of this factor increases by one unit, the quality of the internship programmes will increase by 2.23 units (considering that the other variables do not change). The smallest value of the regression coefficient is 0.69 for the factor "Bureaucracy and accessibility". Therefore, in the present case the regression equation has the following form:

Quality of internship programme $=17.45+1.65 \mathrm{Job}$ arrangements +1.94 Mentorship and employability benefits +2.23 Learning content +1.18 Academic supervision +0.69 Bureaucracy and accessibility

Considering this equation it can be deducted that in order to increase the quality of internship programmes a key role is played by the Learning content, followed by Mentorship and employability benefits- if these factors are improved, the overall quality of internships is improved. A positive influence is exerted also by Job arrangements and Academic supervision. Also positive, but of a lower intensity is the relation between quality of internships and Bureaucracy and accessibility.

\section{Conclusions}

The present article aimed at providing an overview of the factors which influence the quality of internship programmes in the opinion of graduate and undergraduate students of the Bucharest University of Economic Studies, who participated in the questionnaire based survey. By applying factor analysis there resulted five factors which should be considered when designing and implementing an internship programme: Job arrangements, Mentorship and employability benefits, Learning content, Academic supervision, Bureaucracy and accessibility. By acknowledging these factors, the stakeholders become aware of the measures and means available in order to increase the quality of internship programmes.

The findings of the research depicted above are in line with the results of previous researches related to quality of internship programmes. Similar to other studies, the content of work is considered essential in order to increase the employability chances of students and their practical knowledge. As resulted also from other studies very good mentorship within the organization but also at the university is also crucial, when speaking about quality internships. Job arrangements are also mentioned in various previous studies under the form of "adequate design and good organisation". Bureaucracy is a new dimension, rather specific to the national and local environment.

In a next stage the afore mentioned factors are introduced in a regression model and the results reveal that in order to improve the quality of internships stakeholders should pay special attention to the "Learning content". In order to 
maximize the benefits of an internship programme the tasks performed in the organization should be linked to the field of study and theoretical knowledge delivered in the university. Therefore, it is advisable, that organizations work together with representatives of universities when designing the content of internship programmes. The second most important factor refers to "Mentorship and employability benefits". Special attention should be paid to the way interns are mentored and supported by other employees. Organizations should have designated tutors for interns and other employees should be trained to become aware of the fact that it is important to share information with interns and to support them within the learning process. The third factor refers to "Job arrangements", meaning the way how work of interns is organized within the organization. Before recruiting interns it is recommended that organizations have the proper infrastructure: a working place for interns, a schedule and a clear cut list of activities, feedback sessions and induction period. As revealed by the present study, universities have also to improve the relationship with interns: a better supervision, a focused feedback and support from the academic advisor, a transparent and relevant evaluation procedure are supposed to contribute to the improvement of internship programmes. The bureaucracy should be also diminished and optimized.

It can be observed that the five factors revealed by the analysis explain to a large extent (over 50\%) the quality of internship programmes. This result confirms the relevance of the research: if stakeholders manage to optimize the five factors and to apply the proper measures there is a high chance that the quality of internships is improved. In the optimization process are involved organizations, universities, state and institutions which provide the legal framework and direct beneficiaries (students).

Therefore, the main contributions of the present article to knowledge advancement refers on one hand side to the ranking of the major factors which influence the quality of the internship programmes, thus knowing the mechanisms which should be triggered in order to enhance the quality of internships. On the other and side the research methodology provides sufficient information as to help other researchers reiterate this particular research in other fields of study or geographical areas, if considered appropriate.

The main limitations of the present study refer to the geographical distribution and to the errors that might result from the transcription of the questionnaires in the electronic data base. In a next phase, it is recommended that more universities (fields of studies) from various regions are involved in the research and as much as possible questionnaires are distributed in an electronic format, so that results can be automatically transferred in the data base.

\section{References}

Alpert, F., Heaney, J-G., Luhn, K.A. (2009), "Internships in marketing: Goals, structures and assessment - student, company ad academic perspectives", Australasian Marketing Journal, Vol. 17, pp. 36-45. 
Bailey, T., Hughes, K. and Barr, T. (2000), "Achieving scale and quality in school-towork internships: Findings from two employer surveys", Educational Evaluation and Policy Analysis, Vol. 22, No. 1, pp. 41-64.

Bay, J. (2006), “Preparing undergraduates for careers: An argument for the internship practicum”, College English, Vol. 69, No. 2, pp. 134-141.

Beard, F. and Morton, L. (1999), "Effects of internships predictors on successful field experience", Journal of Mass Communication Educator, Vol. 53, No. 4, pp. 42-53.

Beck, J. E. and Halim, H. (2008), "Undergraduate internships in accounting: What and how do Singapore interns learn from experience?", Accounting Education: An International Journal, Vol. 17, No. 2, pp. 151-172.

Bhaskar, A. (2009), "People development: The intangible contribution of HR to business", NHRD Network Journal, Vol. 2, No. 4, pp. 1-4.

Cho, M. (2006), "Student perspectives on the quality of hotel management internships", Journal of Teaching in Travel \& Turism, Vol. 6, No. 1, pp. 61-76.

Chouinard, N. (1993), "Some insights on meaningful internships in sport management: A cooperative education approach", Journal of Sport Management, Vol. 7, No. 2, pp. 95-100.

Ching-Sung, L. and Chen-Wei C. (2013), "intention to "leave" or "stay" - the role of internship organization in the improvement of hospitality students' industry employment intentions", Asia Pacific Journal of Tourism Research, Vol. 18, No. 7, pp. 749-765.

Coll, R.K., Eames, C., Paku, L., Lay, M. (2009), “An exploration of the pedagogies employed in work integrated learning", Journal of Cooperative Education and Internship, Vol. 43, No. 1, pp. 14-35.

Craciun, L., Nastase, M., Stamule, T., Vizitiu, C. (2015), "Leadership in Romanian small to medium enterprises", Sustainability, No.7, pp. 4183-4198.

Cuyler, A. and Hodges, A.R. (2015), "From the student side of the ivory tower: An empirical study of students' expectations of internships in arts and cultural management", International Journal of Arts Management, Vol. 17, No. 3, pp. 68 79.

Dessler, G. (2013), Human resource management, 13 th edition, Pearson, New York.

European Quality Charter on Internships and Apprenticeships, available on line at: qualityinternships.eu, accessed on October $15^{\text {th }} 2016$.

European Youth Forum (n.d.), Quality internships, available on line at: http://www.youthforum.org/quality-internships/, accessed on October $20^{\text {th }}$ 2016

Gaudreau, P.A., Kufel, A.P. and Parks, D.J., (2006), "Quality internships for school leaders: Meeting the challenge", AASA Journal of Scholarship and Practice, Vol. 3, No. 3, pp. 27-30.

Girard, T.C. (1999), "Interns perceptions of internships: A look at work, supervision and appraisals", Journal of Cooperative Education, Vol. 34, No. 3, pp. 42-46.

Gryski, G.S., Johnson, G.W., O’Tool, Jr. L.J. (1987), “Undergraduate internship: An empirical review", Public Administration Quarterly, Vol. 11, No. 2, pp. 150-170. 
Hurst, J.L. and Good, L.K. (2010), "A 20-year evolution of internships: implications for retail interns, employers and educators", The International Review of Retail, Distribution and Consumer Research, Vol. 20, pp. 75-86.

Knouse, S., Tanner, J. and Harris, E. (1999), "The relation of college internships, college performance and subsequent job opportunity", Journal of Employment Counseling, Vol. 36, No. 1, pp. 35-41.

Knemeyer, M.A. and Murphy, P.R. (2002), "Logistics internships: Employer and Students Perspectives", International Journal of Physical Distribution and Logistics Management, Vol. 32, No. 2, pp. 135-152.

O'Hara, B.S. and Shaffer, T.R. (1995), "Details and student perception of an experiential program for personal selling and purchasing classes", Journal of Marketing Education, Vol. 17, No. 1, pp. 41-48.

Prabhu, B.V. And Kudva, A.S., (2016), "Success of student internship in engineering industry: a faculty perspective", Higher Education for the Future, Vol. 3, No. 2, pp. 164-182.

Radu, C. (2014), "Emotional intelligence - How do me motivate our students?", Procedia - Social and Behavioral Sciences, Vol. 141, pp. 271-274.

Shoenfelt, E., Kottke, J. and Stone, N. (2012), "Master's and undergraduate industrial/organizational internships: Data-based recommendations for successful experiences", Teaching of Psychology, Vol. 39, No. 2, pp. 100-106.

Staiculescu, C., Lacatus, M.L. and Richiteanu Nastase, R.E. (2015), "Students' career counseling - a need in contemporary universities. career counseling services provided by career counseling center of Bucharest University of Economic Studies", Review of International Comparative Management, Vol. 16, No. 4, pp. 506-513.

Starr-Glass, D. 2006. "Enhancing the transformative potential of business internships", Managing Global Transitions, Vol. 4, No. 4, pp. 285-297.

Tang, Y. (2012). "The mode of theoretical knowledge and practical knowledge combination: The significance of internship", World Journal of Education, Vol. 2, No. 4, pp. 55-63. 